U NIVERSITY OF COPENHAGEN

\title{
Enforcement of social rights - Upholding of obligations in Denmark
}

Jacqueson, Catherine

Publication date:

2015

Citation for published version (APA):

Jacqueson, C. (2015). Enforcement of social rights - Upholding of obligations in Denmark. 


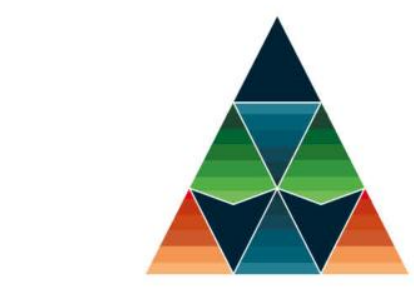

\title{
BEUCITIZEN \\ BARRIERS TOWARDS EU CITIZENSHIP
}

\section{WP 6.4 REDRESS STRUCTURES}

\section{Enforcement of social rights - Upholding of obligations in Denmark}

Author:

Associate Professor, PhD Catherine Jacqueson ${ }^{1}$

Faculty of Law, University of Copenhagen

\author{
Document identifier \\ WP 6.4 \\ Version \\ 1.0 \\ Date due \\ Submission date \\ 14 December 2015 \\ Work Package \\ WP6.4 \\ Lead beneficiary \\ Dissemination level \\ PU
}

\footnotetext{
${ }^{1}$ I would like to thank Prof. Ulla Neergaard and Post-doc Silvia Adamo for their useful comments and their precious support. I am also embedded to assistants, Anders Trebbien Daugaard and Tine Pedersen, for data collection.
} 


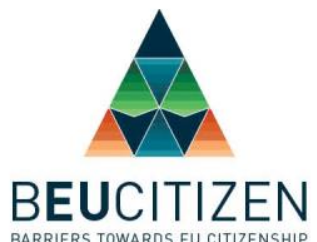

BARRIERS TOWARDS EU CITIZENSHIP 


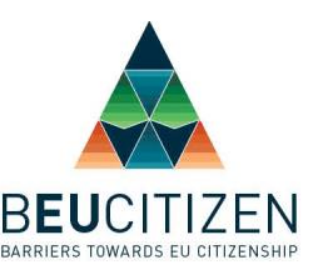

\section{Overall system of redress structures in the field of social rights}

\subsection{Overview}

According to the Danish Constitution (Section 82), municipalities shall have competence to decide on their own affairs, and have competence to levy taxes. For the purpose of our study, municipalities were competent in the social area concerning benefits in cash (social assistance and housing), lower education and specific types of health care. Yet, since 2012 social benefits in cash are to a great extent administrated by a newly established central organ, the Danish Payment Agency (Udbetaling Danmark). It is intended to ensure good use of existing digital possibilities and make municipal payments more efficient by placing them in one instance. Decisions on social assistance are still the competence of the municipalities, while the Agency deals with housing benefits. Decisions of the municipalities and the Danish Payment Agency can be appealed before the National Social Appeals Board and/or tried before ordinary courts.

Health care is predominantly the responsibility of the regions and decisions can be appealed before two different complaints boards. Decisions on student maintenance grants are adopted by the Study grants Authority and can be tried by a specific complaint board. Recourse to ordinary courts is nevertheless also always possible (section 1.2) and legal aid might be obtained under strict conditions (section 1.3). Yet, the administrative complaints system is a corner stone in the protection of social rights in Denmark (section 1.4). In all the mentioned areas of social law, the Parliamentary Ombudsman can be seized where administrative remedies have been exhausted (section 1.5). Finally, several public bodies are responsible for ensuring supervision of public authorities in the social field (section 1.6).

\subsection{The court system}

The Danish court system is regulated in the Constitution (Art. 3 on the separation of powers) and in the Administration of Justice Act, and is organised according to a three tier-system. ${ }^{2}$ All decisions in the social field taken by the municipalities, the Danish Payment Agency, the health practitioners and institutions, the regions and the student administration can be tried before ordinary courts of first instance (byret). Decisions can be appealed before one of the two regional courts of appeal (landsret) and if leave has been granted the case might finally be assessed by the Supreme Court (Højesteret). There is no constitutional court in Denmark, but the constitutionality of laws can in principle be tried before ordinary courts even though this is rarely done in practice. There are no administrative courts either ${ }^{3}$ and 'disputes between the citizens and public authorities are dealt by ordinary courts or quasi-judicial boards of appeal in an intermediate stadium between public authority and courts'.

\footnotetext{
2 Adamo (2015) at p. 42.

${ }^{3}$ See further Conradsen and Gøtze (2014) at p. 155.

${ }^{4}$ Adamo (2015) at p. 42 who refers to Melchior (2002) at p. 115.
} 


\section{A \\ BEUCITIZEN}

Courts are increasingly used in the social field even though the procedure is time consuming and expensive. This is especially the case where big interest organisations, such as unions have an interest on behalf of their members in obtaining a clarification of a general character which courts can give. ${ }^{5}$ Another situation is where the complainant obtains legal aid (fri proces). Furthermore, with the exception of health care, courts are the only instances competent to assess claims for damages and compensation when social rights are breached. Yet even in cases where the costs are covered by the state or the unions, the long time-frame of such procedures might be a psychological hindrance for having the case tried before courts. In addition, in the social area, it is in most cases of major importance to obtain a decision rapidly which works against having the case tried by courts. ${ }^{6}$

If we look at numbers and outcomes of courts cases for 2011, the percentage of cases where courts upheld the decisions of the National Social Appeals Board is very high, viz. $95 \% .{ }^{7}$ But for the same year, only $3 \%$ of the decisions of the Board were brought before the courts. ${ }^{8}$ The vast majority of decisions of the Board brought to courts in 2010 concerned children and occupational injury. ${ }^{9}$

\subsection{Legal aid}

Two types of legal aid

Citizens have access to legal aid in the form of counselling provided by various actors, be they charities specialised in a given field or legal aid organisations supported by the municipalities (retshjoelpen). It is possible to obtain legal aid in court proceedings (fri proces) on conditions of resources in specific situations. ${ }^{10}$ A lawyer is then appointed by the court to represent the citizen at the state's costs. The costs of the procedure are normally paid by the 'losing party' including the costs incurred by the 'winning' party, but when the citizen has been granted legal aid, all costs will then be covered by the state. This might include those linked to the preparation and clarification of the case such as the hearing of witnesses and covers also proceedings in second and third instances if the case is appealed by the opposite party and the party who has been granted legal aid wholly or partly won the case in the previous instance.

\section{Conditions}

Legal aid in court proceedings is granted on conditions of resources. For example, for 2015 an individual may not earn more than DKK 304000 (approx. 40750 Euros), DKK 386000 (approx. 51740 Euros) for a couple with an addition of DKK 53000 (approx. 7104 Euros) per child. These levels include revenues from capital. Besides the condition of resources, the situation also has to fall within one of the categories specifically mentioned by the

\footnotetext{
${ }_{6}^{5}$ Ketscher (2013) at p. 358.

${ }^{6}$ Ketscher (2013) at p. 358.

${ }^{7}$ Conradsen and Gøtze (2014) at p. 167.

${ }^{8}$ Conradsen and Gøtze (2014) at p. 167.

${ }^{9}$ Andersen (2013) at p. 392.

${ }^{10}$ Regulated by the Administration of Justice Act (retsplejeloven).
} 


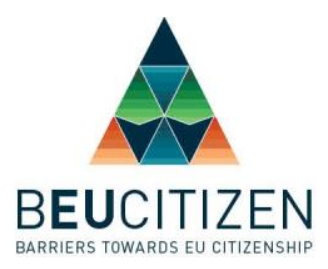

Administration of Justice Act. ${ }^{11}$ In the area of social law, one of those situations is when the individual has 'won' a case before an Appeals Board but the decision has been appealed. There is an additional condition of likelyhood of winning the given case which has to be fulfilled. In practice, the Board might represent the individual before the court. In addition, the Ombudsman can recommend that legal aid for court-proceedings shall be given. He can thus ensure that legal uncertainties reach and are settled by courts. ${ }^{12}$

\subsection{Administrative complaints boards}

In Denmark, administrative complaints systems are of first and major importance in upholding individual social rights. They are indeed the rule whereas judicial review is the exception. ${ }^{13}$ Pursuant to the General Administrative Act (forvaltningloven), the administration shall give guidance on administrative review where the application of the party is not fully met. ${ }^{14}$ There is a myriad of sector-specific boards of appeal and essentially three main boards are relevant for the purpose of our study: The National Social Appeals Board which assesses issues relating to social assistance and housing benefits, the National Agency for Patients' Rights and Complaints (now the Authority for Patient Safety) dealing with claims concerning health care and the Appeals Board for Study Maintenance Grants and Loans.

The regulatory framework of administrative review 'is both vast and diverse as it consists of a combination of legal principles and a myriad of statutory rules governing specific sectors' ${ }^{15}$ While their competence and procedure vary, they have a certain number of features in common. Their aim is to ensure that the individual can have individual 'decisions' reviewed easily and quickly. Access to complaint boards is usually free of charge and the procedure is written. There is no need to be represented by a lawyer but this might be an advantage. Depending on the nature of the cases, the boards have the possibility to rely on experts. Their composition varies and in practice they are mostly composed by people with a legal background. In most cases, the reviewing authority may carry out a full review of all aspects of the case, factual as well as legal, and may also review the appropriateness of the legal act, something that courts and the Ombudsman are normally reluctant to do. ${ }^{16}$

\subsection{The Parliamentary Ombudsman}

The Parliamentary Ombudsman plays an essential role as there are no administrative courts in Denmark. The Ombudsman is appointed by the Parliament and is responsible for controlling all parts of the administration. ${ }^{17}$ Anyone can complain to the institution, but the latter is free

\footnotetext{
${ }^{11}$ See further Bang-Pedersen \& Christensen (2015) at pp. 473-478.

${ }^{12}$ Madsen, H. B. (2010) at p. 446.

${ }^{13}$ Conradsen and Gøtze (2104) at p. 157.

${ }^{14}$ Conradsen and Gøtze (2104) at p. 156.

${ }^{15}$ Conradsen and Gøtze (2014) at p. 156.

${ }^{16}$ Conradsen and Gøtze (2014) at p. 163.

${ }^{17}$ Lov nr. 473 om Folketingets Ombudsmand, 12. juni 1996.
} 


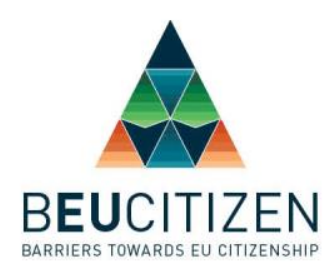

to decide which claims it will take on and can dismiss the others without further ado. Claims shall be submitted within a year from the date of the decision/action and all administrative remedies shall be exhausted. The Ombudsman is thus a fall-back institution. ${ }^{18}$ In addition, the Ombudsman can decide ex officio to take up a case under examination. Finally, the Ombudsman also has investigation powers in respect of public institutions such as prisons and psychiatric hospitals.

The Ombudsman is not part of the administration, but acts in accordance with the General Administrative Act (forvaltningsloven), the Access to Information Act (offentlighedsloven) and the Data Protection Act (persondataloven). The procedure is written. The institution assesses whether the public administration has acted in accordance with the rules in force and also whether they have respected the unwritten principle of good administration. It has several means of action at its disposal: the institution can express criticism, make recommendations or otherwise issue opinions. While Ombudsman's statements are not binding on the authorities, in practice they are in the vast majority of cases followed and highly respected. ${ }^{19}$ In 2013, the Ombudsman dealt with 659 cases assessed by the National Social Appeals Board. ${ }^{20}$

\subsection{Supervision of public decision-making}

As mentioned above, two instances are nowadays taking individual decisions in the social field strictly understood: the municipalities (for our purpose essentially in respect of social assistance) and the National Payment Agency (for our purpose essentially housing benefits). They act under the responsibility of different instances which shall ensure that they respect the law. The State Administration is a central organ and is the control instance for the municipalities. ${ }^{21}$ It is also competent to adopt individual decisions in various fields, such as divorce, adoption and residence for Union citizens. Its supervisory competence is limited as there are many situations that it cannot deal with. It decides sovereignly which case it will take up for further scrutiny, and may issue preliminary statements on the legality of the municipality's action/decision and in exceptional cases adopt sanctions.

The Danish Payment Agency is under the control of the Social Ministry to which it has to report on a yearly basis. ${ }^{22}$ In addition, the National Social Appeals Board yearly reports on the decision of the Agency that it has reviewed.

The area of health care is administrated by the regions which are responsible for supervision of the relevant institutions (public hospitals and private practitioners and clinics with which it enters into agreements). In addition, health care is under supervision of the Danish Health Authority/The Danish Patient Safety Authority (Sundhedstyrelsen/Styrelsen for

\footnotetext{
${ }^{18}$ Conradsen and Gøtze (2014) at p. 156 and Gøtze (2010).

${ }^{19}$ Conradsen and Gøtze (2014) at p. 172-173.

${ }^{20}$ Report on the activities of the Ombudsman for 2013.

${ }^{21}$ See further, Andersen (2013) chapter 11 and Lov nr 542 om regional statsforvaltning, 24/06/2005 with further amendments.

${ }^{22}$ Lov nr. 324 om Udbetaling Danmark, 11 April 2012.
} 


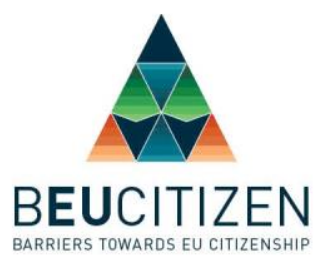

Patientsikkerhed) which controls proactively and/or reactively both (public and private) institutions and individuals (health practitioners). ${ }^{23}$

\section{Protection of social rights at a general level}

In Denmark, both procedural rights and substantial rights in the social field can be assessed as strong rights as the following discussion will demonstrate.

\subsection{Strong procedural rights}

The procedures for complaining about decisions in the social field are well-defined and put in statutory law (for example, the Social Legal Certainty Act). Most procedures for reviewing a decision before a complaint board are 'informal', free of charge and written. This is for example the case before the National Social Appeals Board, but the Board can decide to hear the complainant even though it rarely makes use of this possibility. In case of language barrier, interpretation might be provided at the cost of the state and claimants can be represented by a lay or legal person at their own cost. Legal help in proceedings before courts, including the costs for a lawyer, can be granted where the conditions thereof are fulfilled, cf. section 1.3.

Complaints boards are bound by their general goal and rules as well as by the principles of reaching decisions within a short time-frame and according to the principle of dialogue. ${ }^{24}$ They shall also respect the procedural requirements deriving from EU law and can ask preliminary questions to the CJEU in case of doubt concerning the interpretation of EU law. Yet, the National Social Appeals Board has never made use of this possibility even though it is acting in a field which is heavily regulated by EU law and the CJEU case-law. In contrast, the Appeals Board for Study Maintenance Grants and Loans requested a ruling from the CJEU on equal treatment of workers in respect of payment of maintenance grants to students who are working besides their studies, cf. case C-46/12, $L N$. The boards shall also respect human rights as guaranteed inter alia by the European Convention on Human Rights. The Convention's Art. 6 on access to justice and Art. 13 on effective remedies are also applicable in respect of the complaints boards. ${ }^{25}$

\subsection{Strong substantial rights}

The right to social assistance for persons legally residing in Denmark who cannot provide for their own needs (no fortune, no spouse or partner who can provide for them) is guaranteed by the Constitution in its Section 75 and in the Active Social Policy Act. ${ }^{26}$

\footnotetext{
${ }^{23}$ For more details, see Hartlev et al. (2013) at pp. 115-124.

${ }^{24}$ Ketscher (2013) at p. 401 concerning the National Social Appeals Board.

${ }^{25}$ Ketscher (2013) at pp. 401-402.

${ }^{26}$ Bekendtgørelse af lov om aktiv socialpolitik, LBK nr. 806, 1 July 2015.
} 


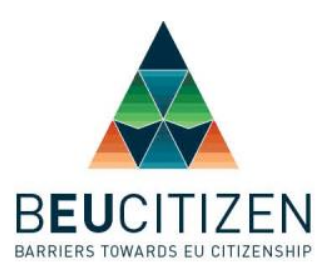

The rights under consideration in the present study can be assessed as rather strong since the discretion left to the authorities is small and 'decisions' can be fully reviewed by complaint boards and courts. Yet, such rights can be amended by a majority in the Parliament. The right to social assistance and free access to schools are protected at constitutional level and seem therefore to be the strongest. Indeed, they cannot 'disappear' without an amendment of the constitution. On the other hand, concerning social assistance, its level and conditions can be changed over time and the question is to which extent Danish courts will ensure that it is not substantially affected in breach of the state's constitutional obligation. The Supreme Court had to assess whether the amendment to the social assistance scheme in 2002 introducing a lower level assistance to eligible citizens who cannot demonstrate 7 years of residence out of the last 8 years was breaching the Constitution. ${ }^{27}$ The legal action essentially targeted two questions: (1) was the level of the benefit sufficient in light of the right to social assistance protected at constitutional level (Section 75(2) of the Danish Constitution), and (2) did it amount to discrimination on grounds of origin/ethnicity contrary to inter alia EU law, the European Convention of Human Rights and the Convent on Refugees? Both claims were dismissed by the Danish Supreme Court. ${ }^{28}$ The Supreme Court emphasised that the Constitution guarantees a right to minimum means of subsistence which can be subject to judicial review. This is the first time a Court clearly states that Section 75 of the Constitution is judicially enforceable. The Court pointed out that the Afghan refugee and his family had in the given case received other forms of public help (like housing and medical help) in addition to the reduced social assistance. It therefore concluded without further ado that his constitutional right had not been breached. Compared to the clear and transparent criteria used by the German Constitutional Court in assessing whether a given amount is sufficient in the light of the person's integrity and dignity, it is unclear how the Danish court arrived at its conclusion and the decision lacks therefore transparency. ${ }^{29}$ Concerning the alleged claim of discrimination on grounds of ethnicity, the Supreme Court accepted that the benefit is covered by art. 1 in Protocol 1 to the Convention on Human Rights (inalienability of property) and therefore should not discriminate. Yet, the Danish Supreme Court emphasised that the purpose of the reduced level of assistance was to encourage return to the labour market and immigrants' integration into Danish society. The court found that it was necessary to restrict the circle of beneficiaries in the light of the specificity of a tax-financed welfare system like the Danish one. It was therefore legitimate to condition access to social assistance to demonstrating a sufficient link to the Danish society even if this could affect more immigrants than Danes.

According to the Health Act, patients shall have access to free health care. Health care is broadly defined as including examination, treatment, re-education and prevention, but the Act does not list the types of services/treatments the patient is entitled to. ${ }^{30}$ In an EU law perspective and in respect of treatment subject to prior authorisation, patients who cannot obtain the necessary treatment in due time in the Danish 'public' sector, shall be authorised to

\footnotetext{
${ }^{27}$ Lov nr. 361 om andring af lov om aktiv socialpolitik og integrationsloven, 6. juni 2002. The following discussion on the Supreme Court case is taken from Jacqueson (2016).

${ }^{28} \mathrm{U} 2012.1761 . \mathrm{H}$.

${ }^{29}$ BVerfG, 1 BvL 1/9 vom 9.2.2010, Absatz-Nr. (1-220) Hartz IV. See Ketscher(2012) at p. 180.

${ }^{30}$ Hartlev et al. (2013) at p. 229.
} 


\section{A \\ BEUCITIZEN}

obtain equivalent or better treatment in another Member State on behalf of the Danish state, cf. C-173/09 Elchinov. It is the practitioner who decides which kind of health service shall be proposed to the patient after consultation with the patient. There is in other words no right to a specific health treatment.

The Constitution guarantees free access to education for children (Section 76). In addition, Danish students are entitled to maintenance grants (SU). The same is true under some conditions for Unions citizens and third country nationals. Finally, housing allowances are accessible without conditions of nationality.

\section{Redress structures in relation to relevant actors}

\subsection{Public supervisory bodies}

Municipalities have a general obligation to act in compliance with the law. The Ministry of Social Affairs is essentially responsible for guiding the municipalities in exercising their competences in compliance with the law. The Public Administration (statsforvaltningen, institution at national level) has competence to ensure that this is actually the case. The supervisory body cannot change concrete decisions, but can annul them. This is only possible when there is no possibility of administrative appeal. This general control organ has especially had influence in the area of social law when there is no possibility of administrative appeal or where the situation falls outside of the complaints board's competence because it does not constitute a 'decision'. 31

The case of homeless Union citizens is one of those cases where the State administration upon a claim from DanChurch, a Danish NGO, asked the municipality of Copenhagen to provide further information on access by Union citizens to shelter homes. ${ }^{32}$ The NGO claimed that the municipality had instructed public shelter homes to refuse EU-migrants who could not document lawful residence through the Danish Health Card contrary to EU law. Yet, upon receipt of the municipality's reply the supervisor body decided not to scrutinize the case further as it was not convinced that the municipality had infringed the law. ${ }^{33}$ In its assessment, it essentially emphasised that the municipality of Copenhagen had followed the instructions issued by the Ministry of Social Affairs which had been revised in December 2014 to the benefit of EU homeless migrants. This issue illustrates how the NGO used the supervisory body to put pressure on the municipality to respect in practice the instructions of the Ministry.

\footnotetext{
${ }^{31}$ Ketscher (2014) at p. 354.

32 http://www.kk.dk/sites/default/files/edoc/a5a81e9d-f520-4664-95fa-cc45301a8734/5c09d613-664d-498e832d-6b0d34f481d5/Attachments/12536261-13572190-1.PDF

33 https://www.kk.dk/sites/default/files/edoc/3532c7e6-e822-41d3-a643-a49f57d523f5/4d57071e-8e64-4a41be74-c1ba2443d726/Attachments/13157825-14631625-1.PDF
} 


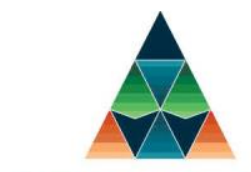

BEUCITIZEN

BARRIERS TOWARDS EU CITIZENSHIP

\subsection{Complaints boards, the law and the lawyers}

The National Social Appeals Board (Ankestyrelsen) has traditionally been composed of people who are involved in interest organisations, for example in the municipal council, unions, and handicap organisations. Such persons thus have a knowledge of the situations they have to decide on, but they are not necessarily lawyers and do not need to be lawyers. The Act on Legal Certainty attempts to ensure legal expertise in the decision-taking requiring that the head and deputy-head of the board and the heads of sections shall be lawyers, political scientists or economists. Yet, this requirement does not seem to be sufficient to ensure the legal expertise of the National Social Appeals Board, ${ }^{34}$ even though in practice heads of sections are to a great extent lawyers. Yet, cases are prepared by the board's 'secretariat' which is constituted by a vast majority of lawyers. Decisions can be adopted with or without additional appointed members. The latter are lay members appointed by the ministry after proposal by the social partners' central organisations and the Danish organisation for handicapped. ${ }^{35}$ It is essentially in cases of principle, that decisions shall be adopted in a meeting with enlarged voting rights with two members and two heads of sections and eventually the head of the Board or the vice-head. In some cases, it is obligatory to ensure extended voting rights, for example for decisions adopted in respect of children and young persons. Decisions are always adopted by a simple majority.

The Equality Board is competent for dealing with cases concerning discrimination, essentially in respect of sex, ethnicity and race. It can only intervene in so far all administrative appeal procedures have been extinguished. Likewise it cannot treat a case which is dealt with by courts. Decisions of the Equality Board are binding on the administration. The board is composed of lawyers, its president being an appeal judge or the president or vice-president of the Sea and Commerce Court, and its vice-presidents shall be district judges.

The Patient Safety Authority relies on a network of more than 300 experts and on the Health Authority for further information. ${ }^{36}$ It is in practice composed of a combination of health professional and lawyers. The Ministry of Health also appoints a number of members who are lay persons and persons within the health profession. The health area is one where an alternative dispute resolution was introduced by statute in 2011. It compels hospitals to propose a dialogue to the patient who has filed a complaint. The purpose of such scheme was explicitly to reduce the number of complaints. This was only partially achieved in the following year with $44 \%$ of the affected patients withdrawing their complaint subsequent to the dialogue but with only $17 \%$ of patients accepting the dialogue in the first place. ${ }^{37}$

The procedure before the complaint boards is inquisitorial where the boards assess on their own the legal dispute and which legal provisions might be involved, including in principle issues related to EU law and/or international law.

\footnotetext{
${ }^{34}$ Ketscher (2014) at p. 352.

${ }^{35}$ Ketscher (2014) at p. 352.

${ }^{36}$ Hartlev et al. (2013) at p. 295.

${ }^{37}$ Conradsen and Gøtze (2014) at p. 173-174.
} 


\section{A \\ BEUCITIZEN \\ BARRIERS TOWARDS EU CITIZENSHIP}

\subsection{The Ombudsman}

Finally, the Ombudsman is also exercising control over the public administration and bodies. $\mathrm{He} / \mathrm{she}$ is appointed for 6 years by the Parliament and can be seized by the individual when the administrative appeal possibilities have been exhausted or when there is no such possibility of appeal. The Ombudsman also has competence to take up an issue on his/her own motion and examine whether the municipalities have acted in compliance with the Social Legal Certainty Act, the General Administrative Act, the Access to the Public Act, human rights and EU law. In November 2012 a special office dedicated to children was established within the institution of the Ombudsman which shall inter alia ensure compliance with the UN Convention on Children's Rights. ${ }^{38}$ The Ombudsman can ask questions/collaborate to the European Ombudsman in order to ensure a more efficient protection of the rights and interests of Union citizens. To my knowledge this possibility of collaboration has only been used once in a case concerning a refusal of the Danish authorities to provide a study maintenance grant on an equal treatment basis to a German national studying and working in Denmark. The Danish Ombudsman who enquired into the compliance of the Appeals Board for Student Maintenance Grants and Loans' rulings with EU law, sought guidance on the interpretation of EU law before the European Ombudsman. Yet, the European ombudsman never had a chance to address the issue since the question was withdrawn following the Board's decision to ask a preliminary question to the CJEU. This led to the $L N$-case where the Court ruled in favour of the German citizen. Procedures before the Danish Ombudsman are free of charge, but there is no obligation of the Ombudsman to take the case further. It is not unusual for citizens to be represented by lawyers in their claims before the Ombudsman.

\section{Extra-legal hindrances to enforceability of social rights}

One hindrance which might be more accurately assessed as a legal one than as an extra-legal hindrance is information of the citizens' rights. Indeed, most of the Appeals Boards under examination in this study have an internet site where useful information can be found. Yet, for most of them the information that is available in English or in other languages is very poor. On the other hand, it might be possible to have access information upon specific request and in most cases English could be used as a communication language. Yet, decisions adopted by the Danish authorities are issued in Danish, compelling the foreign national to find help in decoding it. It was not possible to find out whether the citizen can claim in another language than Danish. So language might be an extra-legal hindrance.

Procedure before complaints boards are in their vast majority free of charge. Their purpose is essentially to ensure an easy access and quick review of the decisions taken by the administration. The administrative complaints system is thus there to ensure that the citizens' social rights are upheld. In theory all affected citizens shall have access to the review procedure regardless of economic resources. It would be interesting to know the proportion of

${ }^{38}$ Ketscher (2013) at p. 356. 


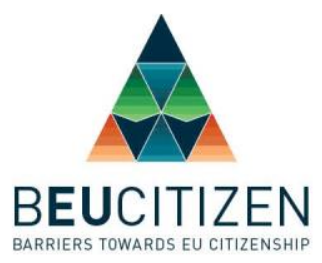

cases before the complaints boards that are in fact led by lawyers, and their success rate. On a final note, interpretation can be granted when necessary, but since procedures are written this is mostly irrelevant.

\section{Specific redress structures}

\subsection{Enforcement of the right to health care}

\subsubsection{Redress structures}

The dichotomy between benefits in kind and in cash is not that relevant in the field of health care as most health care is provided in kind to the patient. It is provided free of charge and financed through general taxes. There are a few exceptions such as dental care for adults where the state only covers a little part of the costs.

The complaint system in relation to health care was amended in 2011 in order to ensure a quicker and easier system of remedies for the patient. ${ }^{39}$ In a nutshell, two boards are competent to assess claims concerning a given treatment: the Disciplinary Committee (Disciplincernovvet) dealing essentially with claims against a given practitioner and The National Agency for Patients and Complaints - which was renamed the Danish Authority for Patient Safety (Styrelse for Patientsikkerhed) in October 2015 - essentially assessing claims on a systemic level. Indeed it assesses claims over treatment given under the responsibility of the municipalities and regions such as hospital care as well as fundamental patient rights (such as issues related to accept, access to documents, secrecy and transplantation). ${ }^{40}$ The Danish Authority for Patient Safety is also responsible for reviewing decisions concerning interpretation and claims for receiving treatment abroad either pursuant to national law or EU law. ${ }^{41}$ This latter assessment spans over various issues such as the necessity of requiring a prior authorisation for treatment abroad, whether the treatment sought is covered by the Danish scheme and reimbursement of the costs. The Authority and the regional patient offices shall aim at informing patients of their rights including their EU-right to receive treatment and the like in another Member State paid by the Danish state. They shall also guide patients in assessing their remedies hereunder compensation for damages. Claims for damages are assessed by the Committee for Patient Compensation (Patienterstatningen) ${ }^{42}$ and decisions can be appealed before the Patient Compensation Appeals Board (Ankencevnet for Patienterstatning).

The Authority for Patient Safety forms part of the public administration and is therefore bound by the General Administrative Act, the Public Access to Documents Act, principles of

\footnotetext{
${ }^{39}$ Lov 706 om aendring af lov om klage- og erstatningsadgang inden for sundhedsvaesenet, 25. juni 2010.

${ }^{40}$ Hartlev et al. (2013) at pp. 292-293.

${ }^{41}$ The Authority is also responsible for administrating the international health insurance.

${ }^{42}$ The procedure for claiming damages is obligatory in the sense that the claim cannot be assessed before courts: Hartlev et al.(2013) at p. 308.
} 


\section{A \\ BEUCITIZEN}

administrative law and unwritten principles on case handling. ${ }^{43}$ Yet, in it is work as complaints body, the Authority acts as an independent body and its decisions cannot be appealed before another administrative body. It might thus be argued that the Authority in its role as complaint body fulfils the EU-conditions for being a 'court' pursuant to Art. 267 TFEU and should thus be entitled to ask preliminary question to the CJEU. The Authority shall propose patients to enter into dialogue with the responsible region for the contested treatment before it assesses a claim. ${ }^{44}$ It has competence to fully review the decisions and can criticise a given institution, confirm, change or annul a contested decision. ${ }^{45}$

\subsubsection{Legal/administrative hindrances}

\section{Residence and personal number}

Access to health services is conditional upon lawful residence in the country and the Health Act intends to ensure easy and equal access for all persons residing in Denmark. ${ }^{46}$ The nub of the issue is then to define lawful residence. In practice it is not sufficient to prove lawful residence pursuant to EU law as access to a myriad of services is conditional upon prior registration in the civil register and obtaining a personal number (cpr nummer) ${ }^{47}$ Residence for the purpose of health care is defined as registration in the civil register. ${ }^{48}$ In respect of Union citizens, registration is only available to those who intend to stay for more than 3 months and is conditional upon presentation of a registration certificate or residence card and proof of domicile for example through a rental contract. The system of personal number is problematic in the light of EU law as it imposes an additional condition to those set up by the Citizenship Directive and might in certain situations constitute an unjustified barrier to the free movement of Union of citizens. The requirement of personal number can, for example, be problematic when the administration is reluctant to issue such a number and the decision is subject to a long delay. Likewise, it is a barrier for Union citizens, such as workers who stay for less than 3 months who might have problems in obtaining a registration certificate. The case is even worse for EU-jobseekers who cannot obtain such a certificate. In addition, homeless Union citizens cannot obtain a personal number as they do not fulfil the condition of domicile. Thus such system of personal numbers might unduly restrict access to health services for those who have the status of worker or self-employed persons under EU law and should therefore be treated on the same footing as Danes. The extent of EU law protection of 'inactive' Union citizens is yet more disputed. Some might argue that as they shall fulfil the double condition of having sufficient resources and a health cover in order not to become a financial burden on the host State, they shall have no access to free health care in the first place.Therefore the argument goes that their protection is more related to fundamental rights than to free movement law. Denmark intends to fulfil its international obligations by entitling all individuals regardless of nationality and residence to receive emergency hospital care for example as a result of a road accident, suddenly arisen illness,

\footnotetext{
${ }^{43}$ Madsen (2010) at p. 431.

${ }^{44}$ Madsen (2010) at p. 431.

${ }^{45}$ Hartlev et al. (2014) at p. 296.

${ }^{46}$ Lov nr. 546 om sundhed, 24. juni 2005, Section 7.

${ }^{47}$ Jacqueson (2016) upon which the following is partly based.

${ }^{48}$ Hartlev et al. (2013) at p. 226.
} 


\section{A \\ BEUCITIZEN}

birth, or a chronic illness that worsens. ${ }^{49}$ On a final note, Union citizens might also have a right to treatment in Denmark pursuant to EU law even though they do not reside there through their home insurance for example through the blue EU health card.

\section{Neglecting the EU right to receive treatment in another Member State}

The general picture in respect of health care is that the Danish authorities have been very slow in 'accepting' and 'implementing' the case-law from the CJEU that money follows the patient. ${ }^{50}$ They have been very skeptical towards patients' EU right to receive scheduled (not emergency) treatment abroad paid by the Danish State pursuant to Art. 56 TFEU. In other words, 'export' of the health care cover has long been refused by the Danish authorities. In fact, it is first with the implementation of the Patients' Rights Directive in December 2013 that the vast majority of patients can freely choose to be treated by a General Practitioner established in another Member State and get the costs reimbursed afterwards. ${ }^{51}$ The situation is similar concerning hospital care. It is first in 2008, upon pressure from the EU-Commission that the Danish authorities put into place a procedure for obtaining a prior authorisation for treatment abroad and informed the population of its EU-right in this respect. In this period, the Patients' Rights Directive was in the process of being adopted. The timing might explain the reluctance of the Danish authorities. Yet, Denmark is normally renowned for its loyal implementation of EU law and one could therefore have expected it to conform to EU law as soon as the directive was adopted. But this has not been the case.

It is interesting to note that the National Agency for Patients' Rights and Complaints (now the Danish Patient Safety Authority) in the period after the adoption of the Directive but before its implementation was more progressive towards EU law. ${ }^{52}$ In its assessment of complaints, the Agency referred directly to the European Court's case-law and did not take the Danish rules on their face value. This is true in respect of medical treatment provided by a doctor established in another Member State where the board claimed that a condition of prior authorisation breached EU law. ${ }^{53}$ Also in 'hospital cases', the board examined case by case whether there was a legitimate planning ground that could justify a requirement of prior authorisation. According to the Agency, not all treatment provided at hospitals could be exempted from patients' free choice. ${ }^{54}$ The Agency was thus more in line with the Directive than with Danish authorities.

Finally, the Danish rules implementing the Patients' rights directive seem to fail on the requirement of providing easily accessible information of the patient on whether a chosen treatment is subject to free choice or requires prior authorisation. Indeed, the list of treatments which are subject to prior authorisation is not very informative. First, the list is difficult to

\footnotetext{
${ }^{49}$ See Ministeriet for Sundhed og Forebyggelse (2014). For a criticism of the Danish position in the light of the UN Convention on social, economic and cultural rights, see Hartlev et al. (2013) at p. 228-229.

${ }^{50}$ The following is mainly based on Jacqueson \& Hartlev (2014) pp. 191-202.

${ }^{51}$ Directive $2011 / 24$ on patients' rights.

${ }^{52}$ Jacqueson (2016) forthcoming upon which the following is based.

${ }^{53}$ The national health board's decision in case No 14POB040, 31 March 2014.

${ }^{54}$ The decisive criterion seems to be whether the treatment only concerns a limited group of patients and where there therefore is a need to preserve national expertise on its territory.For references, see Jacqueson and Hartley (2014).
} 


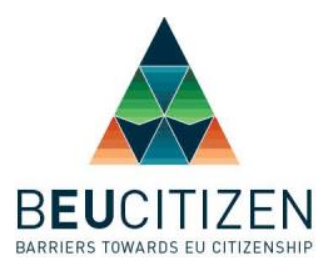

find, and second patients have to find out themselves which diseases and conditions are 'specialised' or 'highly specialised' and thereby subject to prior authorisation. This might be why the authorities advise patients in any event to request a prior authorisation to be on the safe side.

\subsubsection{Extra-legal hindrances}

\section{Interpretation}

Information about a given treatment shall be accessible to the patient who shall have access to an interpreter when this is deemed necessary by the health professional. Besides, patients might want to be assisted by a person of their choice at the information meeting and this shall as far as possible be accommodated by the health person/service. ${ }^{55}$ Furthermore, interpretation shall be granted in all instances where this is deemed necessary. ${ }^{56}$ The interpreter should as far as possible be a professional person and only buy way of exception a family member to the patient. The costs are paid by the public authorities unless the interpreter has family ties with the patient. ${ }^{57}$ Prior to 2011 , it was possible to require patients to pay themselves for interpretation if they had lived for more than 7 years in the country. ${ }^{58}$

\section{Language and exclusion of treatment}

In practice, in situations of complex treatments which span over a long period of time, it can be lawful to deny treatment because of lack of knowledge of the Danish language. ${ }^{59}$ For example, the health professional might refuse to effectuate an operation removing fat in the body, if the person after a concrete assessment does not understand sufficiently Danish to follow the instructions on change of lifestyle and diet. ${ }^{60}$

\subsubsection{Accessibility to rights \& redress for EU-citizens and third country nationals}

Only persons who are lawfully residing in Denmark (meaning those who have a personal number) have access to free health care in Denmark. ${ }^{61}$ The nub of the issue is thus to define lawful residence and some Union citizens might encounter problems in accessing health care services as discussed above. Non-residents might receive scheduled treatment when paid for by their home insurance. Therefore the Health Act was amended in 2013 to include the possibility for hospitals to receive payment. All citizens regardless of nationality and residence have access to emergency care for free. There are no specific remedies for EUcitizens and/or third country nationals.

\footnotetext{
${ }_{55}^{55}$ Hartlev et al. (2013) at pp.161-162.

${ }^{56} \S 50$ in the Act on Public Health.

${ }^{57}$ Bekendtgørelse nr. 504 om tolkebistand efter sundhedsloven, 23 April 2015.

${ }^{58}$ Hartlev et al. (2013) at p. 231.

${ }^{59}$ Hartlev et al. (2013) at p. 239.

${ }^{60}$ Hartlev et al. (2013) at p. 239.

${ }^{61}$ With a few exceptions, such as presentation of the EU blue card in case of emergency treatment.
} 


\section{$A$}

BEUCITIZEN

BARRIERS TOWARDS EU CITIZENSHIP

\subsection{Enforcement of rights related to education}

\subsubsection{Redress structures related to education in kind (services) ${ }^{62}$}

Section 76 of the Danish Constitution provides for free compulsory education to all children. All children regardless of nationality who intend to live in Denmark for more than 6 months are subject to compulsory education either at public school, home or at a school recognised as equivalent by the State. The teaching language in schools is Danish unless an exception has been granted, ${ }^{63}$ and lessons in Danish as a second language are provided for. In 2009, approx. 716200 pupils in the age of compulsory schooling were enrolled at schools in Denmark. Most of them were of Danish origin or had Danish nationality and only $4.5 \%$ were foreigners (mostly nationals from third countries or refugees). Elementary schools are under the responsibility of the municipalities and complaints on access to special needs teaching are assessed by the Appeals Board on Special Needs Teaching (Klagencevnet for Specialundervisning). ${ }^{64}$

Concerning higher education, courses in high schools are generally taught in Danish unless schools have been granted derogation from the Ministry of Education entitling them to teach in French, German or English. Access to high school for pupils who have studied abroad is dependent upon academic qualifications equivalent to those of 'Danish' students. Those qualifications are assessed by the responsible person in each school who might request the pupil to take a test in one or more courses. In 2009, only approx. $3.5 \%$ of high school pupils were foreigners and the majority was from third country nationals or refugees. Complaints on refusal of access to a high school are assessed by the Ministry of Education which only looks into the legality of the decision. ${ }^{65}$

Concerning higher education at professional schools and universities, courses can be taught in other languages than Danish. Yet, Danish institutions might require proof of sufficient knowledge of the Danish language where necessary. Complaints on access to further education are dealt with by the Authority for Higher Education (Styrelsen for Videregående Uddannelser) which will only assess the legality of the decision. ${ }^{66}$ Access to further education on the background of a foreign diploma is regulated by law and complaints are assessed by the Board on Qualifications (Kvalifikationsnaevnet). ${ }^{67}$ The complaints procedures are free of charge and written. In 2008, approx. $8 \%$ of persons studying at Danish professional schools or universities were foreign nationals and this time the majority was EU/EEA nationals. ${ }^{68}$

\footnotetext{
${ }^{62}$ The following is partly based on Jacqueson (2014b).

${ }^{63}$ Udvalg om Udlændinges ret til velfærdsydelser (2011) at p. 178.

${ }^{64}$ Bekendtførelse af lov n. 665 om folkeskolen, 20 June 2014.

${ }^{65}$ Bekendtgørelse (executive order) nr. 128 om optagelse på de gymnasiale uddannelser, 6 February 2015. Complaints on decisions concerning the choice of high school can be assessed by the regional council.

${ }^{66}$ See for example, Bekendtgørelse (executive order) om adgang til bacheloruddannelser ved universiteterne, 16 December 2013.

${ }^{67}$ Bekendtgørelse af Lov nr. 579 om vurdering af udenlandske uddannelseskvalifikationer mv., 1. June 2014.

${ }^{68}$ Udvalg om Udlændinges ret til velfærdsydelser (2011) at p. 183.
} 


\section{A}

BEUCITIZEN

BARRIERS TOWARDS EU CITIZENSHIP

\subsubsection{Redress structures related to education benefits in cash}

Students of Danish nationality and EU citizens who work in Denmark or are family members of workers and self-employed Union citizens are entitled to a maintenance grant $(S U)$. Similarly, they can 'export' the grant for studies in other Member States after a period of two years residence in Denmark. ${ }^{69}$ In addition, Union citizens who have a permanent right of residence in Denmark (5 years) are also entitled to the grant and to export it. The number of Union citizens receiving the study maintenance grant rose from 5077 (where 1045 were from the 10 East-European countries) in 2008 to 11189 in 2013 (where 4229 were from the 10 East-European countries). Union citizens receiving the Danish student grant in 2013 amounts to $2.5 \%$ of the total number of recipients. ${ }^{70}$ Third-country nationals are entitled to the maintenance grant if they fall within one of the categories mentioned in the Executive Order on the study maintenance grant. ${ }^{71}$ This will, for example, encompass foreigners who have stayed in Denmark for more than 5 years provided that they haven't come to the country for the purpose of study.

Decisions on study maintenance grants can be appealed before the Appeals Board for Study Grants and Loans. The Board is chaired by a judge and two others members. In cases concerning students with disabilities, an expert appointed by the Danish organisation for handicapped is also present. Since 2015, cases are prepared by the staff of the National Social Appeals Board. Decisions of the Board are final and binding upon the administration.

\subsubsection{Possible legal/administrative hindrances to fulfilment of rights}

Prior to 2013, the Danish practice concerning access to the study maintenance grant by students was restrictive and uncertain. While inactive Union citizens who did not have a permanent right of residence or were children of workers were automatically excluded from access to the grant, some Union citizens who were working besides their study were lucky in obtaining the grant. This uncertainty (and at times restrictive) practice led the Board to issue a preliminary question concerning students' right to a Danish maintenance grant on an equal treatment basis while studying and working in Denmark. The Danish restrictive practice excluding EU students working in Denmark from this benefit was overruled by the Court in the $L N$-case $(\mathrm{C}-46 / 12){ }^{72}$ The practice was then changed but a close monitoring of the student's worker status followed. The Danish authorities in charge of study grants were indeed strict in their assessment and control over Union citizens' status as workers. ${ }^{73}$ Several complaints cases have thus reached the Appeals Board for Student Maintenance Grants and

\footnotetext{
69 Act on the State's maintenance grant for studies ('SU'), cf. bekendtgørelse af lov nr. 39 om statens uddannelsesstøtte, 15 January 2014 and executive order, cf. bekendtgørelse nr. 792 om statens uddannelsesstøtte, 25 June 2014.

${ }^{70}$ Note from the Ministry for Education and Research to the Parliament's Committte for Europe of the 16 January 2014 ('Orientering om udviklingen i antallet af SU-modtagere og udenlandske statsborgeres ligestilling til dansk $\left.S U^{\prime}\right)$.

${ }^{71}$ Executive order, cf. bekendtgørelse nr. 792 om statens uddannelsesstøtte, 25 June 2014, Section 9.

${ }^{72}$ Jacqueson (2016).

${ }^{73}$ The following is taken from Jacqueson (2014b).
} 


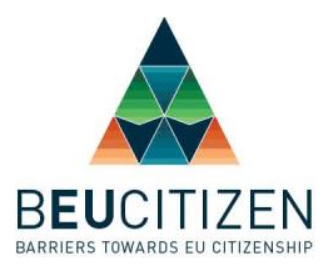

Loans in the last two years. The Board relied directly on the Court's case-law in defining case by case the situations where the Union citizen should be considered as worker (Levin, Genc, raulin, Ninni-Orasche). For example, the Board annulled a decision of the authorities denying the status of worker to a person on the ground that the salary received was symbolic. ${ }^{74}$ The Board found that the citizen had been working 60 hours a month and was subsequently paid a salary which could not be seen as marginal. ${ }^{75} \mathrm{He}$ was therefore entitled to the grant as a worker.

\subsubsection{Extra-legal hindrances to enforcements of rights to education}

No such hindrance could be documented.

\subsubsection{Accessibility to rights \& redress for EU-citizens and third country nationals}

There are no specific remedies available to Union citizens or third country nationals.

\subsection{Enforcement of the right to social assistance}

\subsubsection{Redress structures}

Social assistance is essentially a benefit in cash (kontanthjoelp) which can be topped up by specific help depending on the concrete situation of resources and need of the claimant. As mentioned above, kontanthjoclp is protected at constitutional level. In contrast, supplementary help in cash is provided at the discretion of the municipalities and might thus vary upon the place of residence.

Since 2012 benefits in cash are to a great extent administrated by a newly established central organ, the Danish Payment Agency (Udbetaling Danmark), but social assistance is still administrated by the municipalities which are also in charge of benefits in kind such as child care, elderly care and handicap aid. On a procedural level, municipalities have to act in conformity with the Social Legal Certainty Act. ${ }^{76}$ In addition, they have to respect EU law and human rights when applicable. Furthermore, principles of administrative law still play an essential role also for decisions in the field of social rights, but the tendency is that social law is developing its own sources of law where administrative law is to a higher degree only playing a complementary role. ${ }^{77}$

The National Social Appeals Board (Ankestyrelsen) is since the $1^{\text {st }}$ of July 2013 as a general rule the only administrative complaint organ competent to assess claims against decisions

\footnotetext{
${ }^{74}$ Decision of the Appeals Board, KEN nr 10426, 15/12/2014.

${ }^{75}$ See also Decision of the Appeals Board, KEN nr 10423, 15/12/2014

${ }^{76}$ Udbetaling Danmark is further regulated by the Payment Denmark Act.

${ }^{77}$ Ketscher (2014) at p. 335.
} 


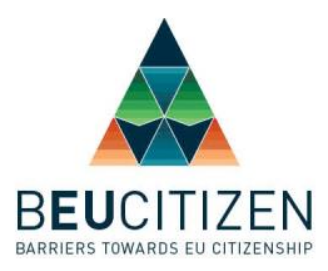

adopted by municipalities in the field of citizens' social rights. Where complaints concern decisions taken by a jobcentre or by the Danish Payment Agency they are assessed by the board's special division called beskaftigelsesudvalget. The board is composed by 'lay judges', who do not necessarily have a legal background and experts play a very little role with the exception of cases involving children.

\section{Advantages}

The National Social Appeals Board presents several advantages to the citizen. Its procedures are 'informal', quick and free of charge, and the Board is thus an essential instrument for the protection of the rights of individuals. ${ }^{78}$ The citizen has 4 weeks to complain upon receipt of the decision provided that he has received instructions on how to proceed and that the decision is sufficiently justified. Otherwise, the deadline might be extended. The complaint has to be sent to the administration which issued the decision which will normally have 4 weeks to reassess its decision. If the decision is confirmed, the municipality has to forward the complaint to the National Social Appeals Board. ${ }^{79}$ The Board shall then assess the case in accordance with the principle of quick expedition unless there is a specified deadline for specific claims.

The procedure before the Board is written, but it can decide to hear the complainant. Yet, it rarely makes uses of this possibility. In case of language barrier, interpretation might be provided at the cost of the state and the person can be represented by a lay or legal person. There is no appeal possible, but the complainant can take the case before the Ombudsman and/or the Equality board. In both cases it is a condition that the legal remedies have been exhausted, ie that the complaint has been assessed by the Board. It is also at any time possible to bring the case before the ordinary court of first instance (byret). Yet, if relevant this will extinguish the procedure started before the Ombudsman.

\section{Limitations}

The National Social Appeals Board also has limits. As a general rule all decisions adopted by the municipalities in the social field, the jobcentres and the Danish Payment Agency can be tried before the Board. ${ }^{80}$ Yet, this does not apply where the decision concerns the municipality's general level of service, the 'tariffs' applied, decisions on child care and private transport of handicapped persons. ${ }^{81}$ Another limitation concerning access to the complaint procedure is that only 'decisions' (afgфrelser) can be assessed. This implies that preparatory acts, recommendations and responses to hearing requests are not covered. Yet, in case of doubt the concept of 'decision' shall be interpreted broadly. Actions taken by the municipality cannot be assessed by the Board as they do not have a legal effect, such as for example the time of delivery of food for elderly people. ${ }^{82}$ Nor can the lack of competence or the behaviour of the employees be seen as decisions. Finally, the same is true as a general rule concerning long time-frames for decisions.

\footnotetext{
${ }^{78}$ Ketscher (2014) at p. 352.

${ }^{79}$ Ketscher (2014) at p. 414.

${ }^{80}$ Ketscher (2014) at p. 403.

${ }^{81}$ Ketscher (2014) 403-404.

${ }^{82}$ Ketscher (2014) at p. 406.
} 


\section{A \\ BEUCITIZEN \\ BARRIERS TOWARDS EU CITIZENSHIP}

\section{Assessment}

The National Social Appeals Board has four possible 'instruments' at its disposal: it can refuse to assess the case, confirm the administration's decision, annul the decision and send the case back to it for a new assessment or change itself the decision. Thus the Board does not have competence to assess the issue of compensation for damages which can only be dealt with by the ordinary courts. In some cases a complaint before the Board can therefore be a waste of time, the only relevant remedy being courts. ${ }^{83}$ There is no reference to the CJEU, even if the Board is a 'court' in the light of EU law and the Board assesses situations which are regulated at EU level.

\section{Level of control}

The National Social Appeals Board is competent to assess both the respect of the procedural aspect of the case as well as the material content of the challenged decision. The control of the formalities and the assessment of the case might also be possible even though the situation cannot be challenged on its material content because of lack of competence (lack of a 'decision'). ${ }^{84}$ Since 2002, it follows explicitly from the Legal Certainty Act that the Board assesses the legal issue of the case and can therefore control whether the authorities have correctly made use of their discretion in the given situation. In other words, the level of control of the administrative complaint body equals to that of courts, so that citizens are not compelled to go to courts to have their case fully tried. ${ }^{85}$ The aim is to ensure that individual rights are upheld and therefore the intensity of the control seems to have increased over time. $^{86}$

\subsubsection{Possible legal/administrative hindrances ${ }^{87}$}

Danish authorities have not been really concerned with social rights stemming from EU law. ${ }^{88}$ This is true in adopting existing law in the social field but also in applying them to concrete cases. This 'negligence' can be explained by several factors such as the fact the Danish law is very national and the municipalities as a general rule refer to the Danish Act and do not enquire into EU law. ${ }^{89}$ So if the law is unclear claims from Union citizens might simply be rejected without more ado.

\section{The concept of worker}

Danish social assistance (kontanthjeelp) is available to all citizens residing in Denmark who cannot provide for their needs - and do not have a spouse/partner who can - and who have no fortune. For the purpose of our study, social assistance is at least available to EU workers

\footnotetext{
${ }^{83}$ See Ketscher (2014) at p. 416 who mentions a case brought before the courts by a union seeking compensation on behalf of a member for stopping the payment of sickness leave which was won by it both before the county court and the appeal court.

${ }^{84}$ On this complex issue, see Ketscher (2013) at pp. 409-410.

${ }^{85}$ Ketcher (2014) at p. 411.

${ }^{86}$ Ketscher (2014) at p. 412.

87 The following builds on Jacqueson (2014) and (2016).

${ }^{88}$ See especially Ketscher (2014).

${ }^{89}$ Ketscher (2014) at p. 285.
} 


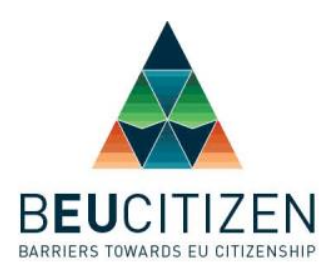

provided that the condition of need is fulfilled. The number of EU/EEA citizens in receipt of social assistance has increased in the period between 2008 and 2012. Yet, the proportion of citizens of other EU states on social assistance in 2012 is still lower than the general proportion of persons on social benefits in Denmark in that age-group in relation to the whole population. ${ }^{90}$ Union citizens who have worked in Denmark and become unemployed there can claim social assistance if they fulfil the conditions thereof. EU-workers are subject to the same conditions as those imposed on Danes meaning that they should be available to the labour market, actively seeking employment and accepting various offers of education and/or work. In practice, there might be problems in respect of who can qualify as a worker pursuant to Art. 45 TFEU as the Danish authorities are more restrictive than the Court. ${ }^{91}$ Another concern is how long EU citizens are entitled to social assistance before they might lose their status as worker and be seen as an unreasonable burden no longer welcome in Denmark. ${ }^{92}$

\section{Discriminating own migrant citizens}

With the accession of the Conservative-Liberal coalition to government in 2001, the Active Social Policy Act was amended after pressure from the Danish People's Party (Dansk Folkeparti, right wing) which supported the minority government. The amendment was openly triggered by migration concerns and it was noted that as the law stood immigrants had access to social assistance on an equal footing with Danish nationals. ${ }^{93}$ This is what the Act intended to remedy with the insertion of a residence requirement of 7 years out of the last 8 years in order to be eligible for social assistance. ${ }^{94}$ Should this residence requirement of residence not be met, citizens might instead be eligible for a newly created lower level of assistance called 'starthelp/starthjoelpen' which level was sat at approx. $65 \%$ of that of social assistance. ${ }^{95}$ The amendment applied to all regardless of nationality. Yet, surprisingly EU citizens were exempted from it and were entitled to the full benefit provided that they were entitled to the benefit under EU law. The amendment was meant to affect immigrants from third-countries. And so it did, especially refugees. But the law had the side effect of also affecting Danes who had left Denmark to work or reside in other Member States. Yet, this did not make the government change its mind. The argument was that neutrality had to be respected under pain of breaching Denmark's international obligations. As long as the law was treating equally (bad) all citizens, it could not be held to be discriminatory on grounds of nationality. ${ }^{96}$ The government was also insensitive to the fact that the amendment breached EU law and the European Court's case-law on the free movement of persons. Indeed as a result of the d'Hoop and subsequent cases, Member States cannot sanction their own nationals for making use of their right of free movement unless this can be justified on objective grounds respecting the principle of proportionality. ${ }^{97}$ In addition, the Court showed

\footnotetext{
${ }^{90}$ Beskæftigelsesudvalget under Beskæftigelsesministeriet (2013).

${ }^{91}$ See further Ketscher (2014) at p. 325-327.

${ }^{92}$ In this respect see the Court's case-law in C-184/99, Grzelczyk, C-456/02, Trojani and C-140/12, Brey.

${ }^{93} \mathrm{Ibid}$. at p. 47.

${ }^{94}$ See L 126 of 2001-2002 om andring af lov om aktiv socialpolitik og integrationsloven.

${ }^{95}$ Such lower assistance had already been introduced only for immigrants in 1998 where it was known under the name of 'introduction benefit' (introduktionsydelse) but had been risen to the level of social assistance in 2000.

${ }^{96}$ Ketscher (2014) at p. 318.

${ }^{97}$ C-224/98, D'Hoop.
} 


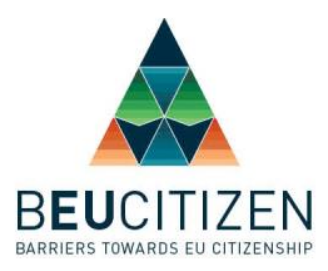

to be strict in its assessment of the proportionality test. Yet, this did not affect the National Social Appeals Board (Ankestyrelsen) which case after case maintained that the law was compatible with EU law and that there was no need to refer a question to the EU Court. For example, a young Dane who had resided with his parents in another Member State in 7 years was only entitled to the starthelp on his return to Denmark after having completed his education abroad. ${ }^{98}$ The underlying rationale seems to be that the principle of equal treatment necessitates that all Danish citizens shall be subject to the restrictive rule on pain of the rule being seen as an unlawful discrimination. The starthelp was reintroduced in a new version in 2015 and renamed the help for integration (integrationsydelse).

\section{Social assistance and lawful residence}

In respect of social assistance, it is clear that Union citizens and their family members have no such entitlement within the first 3 months of their stay and for longer when the Union citizen is a first-time jobseeker. As the Active Social Policy Act provides for public support to all persons in need that are lawfully residing in Denmark, an amendment to the Act was inserted in 2004 as a result of the EU's enlargement to the 10 new Member States. It excludes short-term residents and jobseekers from entitlement to public support except from financial help to get back home. ${ }^{99}$ The rationale is that pursuant to EU law such persons are supposed to be self-sufficient and are therefore not entitled to any financial support from the State. The Act explicitly excludes them from the entitlement to a non-contributory benefit ensuring a minimum means of subsistence (kontanthjoelp). This exclusion of first-time jobseekers might have conflicted with the Court's rulings in Collins (case C-138/02) and Vatsouras (case C-22/08). But the Court recently revised this case-law in Alimanovic (case C-67/14). It defined broadly the concept of social assistance as excluding also benefit schemes for jobseekers which have the dual purpose of both covering the minimum subsistence costs for enjoying a life in dignity and facilitating the search for employment. Thus while the approach adopted by the Danish authorities could be seen as defiant of the Court's previous case-law, one could now argue that they were just being 'clairvoyant'. ${ }^{100}$

\subsubsection{Extra-legal hindrances}

\section{Homeless Union citizens}

Entitlement to social benefits for all other Union citizens residing more than 3 months who are not workers or self-employed shall be assessed case by case. All persons lawfully residing in Denmark are entitled to public support if the conditions for obtaining the benefit are fulfilled. The question would therefore be whether the Union citizen is lawfully residing in Denmark. ${ }^{101}$ This issue has especially been salient in Denmark in respect of homeless persons who are nationals of other Member States concerning their access to shelter homes.

\footnotetext{
${ }^{98}$ Decision of Ankestyrelsen in case 138-09 of 2009.

${ }^{99}$ Act No 282 of 26/4/2004 inserting Sect.12a in the Act No 455 on Active Social Policy of 1997 (Lov om aktiv socialpolitik).

${ }^{100}$ C-67/14, Alimanovic.

${ }^{101}$ See decisions of the Appeal Tribunal for Social and Employment Affairs (Ankestyrelsen) A-191-11 of 8/9/11, A-27-07 of 21/11/07.
} 


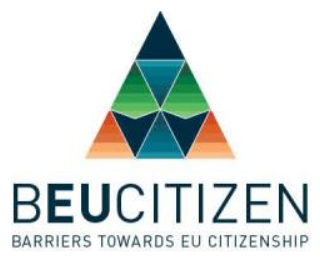

According to Danish law, shelter homes which are to some extent State-funded shall only accept persons who are lawfully residing in the country, this being interpreted restrictively as excluding undocumented citizens. ${ }^{102}$ Such interpretation might conflict with the Directive. The authorities' underlying rationale is that such persons are in any event not lawfully residing in Denmark since they are requesting public support by using shelter homes, and are thereby a burden on the social system.

\subsubsection{Accessibility to rights \& redress for EU-citizens and third country nationals}

The municipalities are in charge of granting social assistance in conformity with the law, including EU law. Decisions can be appealed before the National Social Appeals Board which shall ensure full review both in law and in fact of the individual decision. There is thus no specific appeal body for Union citizens or third country national. Yet, rights granted by EU law and international conventions are more likely to be breached in practice as the municipalities are not always aware of their existence and impact on a given case. The case of discrimination of own nationals on the grounds of migration analysed above is evidence thereof.

\subsection{Enforcement of rights to Housing}

\subsubsection{Redress structures related to housing in kind (services) ${ }^{103}$}

The municipalities are responsible for dealing with problems of social housing and thereby securing temporary housing for those without a roof. Yet, municipalities are not under a legal obligation to find permanent housing for people in need. ${ }^{104}$ According to the Service Act, there is a right to temporary housing for 'homeless' people, provided that this is not the result of their own fault. Such help is in the form of access to shelter or other accommodation. ${ }^{105} \mathrm{In}$ order to solve the problem of more permanent housing for people in need, the municipalities dispose of one essential tool: referring people to social housing (almene boliger). This type of housing is built with financial help from the municipality, but is administrated by private associations according to the Social Housing Act. ${ }^{106}$ The municipalities have a right to dispose over some of the apartments in such buildings, typically 1 out of 4 . There are approx. 500000 social housing in Denmark. Some municipalities also own buildings where they can house people in need of help. This is no longer the case for Copenhagen, the capital city, which sold all its properties in the mid-1990s. Decisions and conflicts related to social housing can be brought before a special complaints Board - The Residents' Complaints

\footnotetext{
${ }^{102}$ Information gathered from the Danish Charity organization, DanChurchSocial (Kirskens Korshaer).

${ }^{103}$ The description is taken from Jacqueson (2014b).

${ }^{104}$ Anker et al. (2002).

${ }^{105}$ The Act on Service ('Serviceloven', LBK nr 1023 af 23/09/2014).

${ }^{106}$ Benkendtgørelse af lov nr. 961 om leje af almene boliger, 11/08/2010.
} 


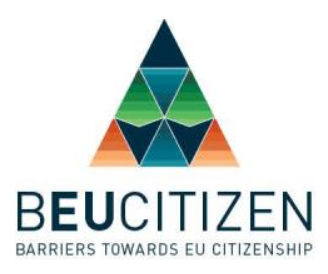

Board (beboerklagencevnet) which are established all municipalities. The Board acts as a kind of first instance body and its findings can be appealed before a special court - The Rent Tribunal (boligretten). The procedure before the Board is easy of access but not free as it is subject to a little fee of approx. 20 Euros. The board and the tribunal deal with various issues related to social housing, such as waiting lists/housing assignments, respect of house rules, and state of the housing at the beginning and the end of the tenancy. The Board is composed of three specialised members where the chairman must be a lawyer, and the two other members are appointed by the representatives of the tenants and the private association. The procedure is written, but the Board can decide to hear the parties. It will always do so in cases of termination of the tenancy.

\subsubsection{Redress structures related to housing benefits in cash}

Danish law provides for housing subsidies to persons and families with low income in order for them to access and remain in decent housing. ${ }^{107}$ The level of the subsidy is defined in accordance with the levels of rent and income as well as the surface of the place and the number of persons living there. Generally subsidies are only given in respect of rented housing with the exception of retired people who might be entitled to the subsidy even if they own their home. ${ }^{108}$ It is in addition a condition for obtaining the subsidy that the person is genuinely using the accommodation which cannot be a summer house. The subsidy is not exportable which can be a problem for pensioners establishing themselves in other EU countries who are in most cases still liable to pay taxes in Denmark of their Danish pension.

According to the Budget Act of 2011, the costs of housing allowances amounted to DKK 11.7 milliard (approx.156 9248102 Euros). Out of the approx. 516000 persons, who received the benefit in 2010, 29700 persons were foreigners (from which 12000 persons were third country nationals, 11200 refugees) thereby amounting to $6 \%$ of the total amount of recipients. ${ }^{109}$ According to a note from the Ministry of Social Affairs from 2014, 10000 Union citizens were in receipt of house subsidies in 2012, a number which had increased with $32 \%$ where compared with the situation in $2008 .^{110}$

Since 2012 housing benefits in cash are no longer administrated by the municipalities but by a newly established central organ, the Danish Payment Agency (Udbetaling Danmark). It is intended to ensure good use of existing digital possibilities and make municipal payments more efficient by placing them in one instance. The agency is under direct control of the Ministry of social affairs which appoints its members. Decisions of the Agency concerning housing benefits can be appealed before the National Social Appeals Board which is discussed above under section 5.3.

\footnotetext{
${ }^{107}$ The following description of housing allowances is taken from Jacqueson (2014b).

${ }^{108}$ Persons with a retirement pension from other Member States are put on an equal footing where the pension is covered by Regulation 883/04.

${ }^{109}$ Udvalg om Udlændinges ret til velfærdsydelser (Commission on foreigners' access to welfare services) (2011) p. 126.

${ }^{110}$ Notat fra Socialministeriet til Europaudvalget om vandrende arbejdstagere rettigheder, 19. februar 2014.
} 


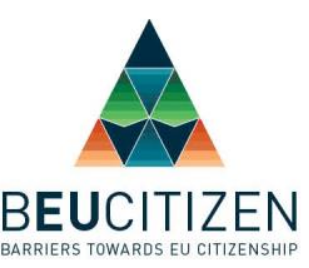

\subsubsection{Possible legal/administrative hindrances}

To my knowledge hindrances are more on the practical level than on the legal level. But some of the hindrances described below might also fall within the category of 'administrative' hindrances.

\subsubsection{Extra-legal hindrances ${ }^{111}$}

As mentioned above, Denmark has long had in place a system of social housing (almene boliger) ensuring that people unable to find accommodation on the 'normal' private market have access to quality housing at reasonable prices. ${ }^{112}$ This sector has long been characterised by an overrepresentation of ethnic minorities (non-Danes). For example, in 1996 the social housing sector was overrepresented by ethnic minorities by $180 \%$, especially foreigners outside the EU. While $60 \%$ of ethnic minorities live in the social housing sector, only $20 \%$ of the total population do. Some social housing areas are thus dominated by foreigners and by people outside the labour market. Therefore, since the 2000s, the authorities have tried to avoid segregation and ghettoization through various initiatives aimed at ensuring more mixed population in social housing. Since 1984, the municipalities have been able to place people in need in 1 out of 4 apartments in social housing. While the selection criterion was solely based on the need for help, since 2005, municipalities can also stimulate people to move out of specific areas in order to avoid ghettoization. In this respect, they can propose financial support to persons who want to move out from these areas, such as help to buy new furniture. Yet this subsidy has rarely been given in practice. ${ }^{13}$ For the remaining proportion of accommodation in such social housing (3 out 4 ) which are administrated by the private associations of inhabitants, the selection rules have also been amended over time with the aim of ensuring that applicants with stronger resources enter disadvantaged areas and thereby remedy ghettoization. Since 1992 people have been put on a waiting list and accommodation has been attributed according to 'seniority'. As a result, renting rules for social housing can best be described as based on a combination of need for housing and seniority. The situation got more complicated since the new millennium with the possibility of using flexible renting. Waiting lists can thereby be disregarded in order to affect the composition of inhabitants in the social housing sector, advantaging specific groups of people deemed to have more resources, who can thereby contribute positively to socially redesigning a given area.

While access to social housing in the fight against ghettoization can negatively affect the possibility of finding housing for ethnic minorities and/or persons outside the labour market, there is no indication that this is negatively affecting EU-nationals. Provided that they fulfil the criteria, Union citizens can be referred to social housing by the municipality or can be registered on the waiting list for social housing. Yet, this requires that Union citizens are

\footnotetext{
111 The following is taken from Jacqueson (2014b).

112 The following is essentially based on Nielsen (2011) at pp. 204-213.

${ }^{113}$ Udvalg om Udlændinges ret til velfærdsydelser (Commission on foreigners' access to welfare services) (2011) at p. 133.
} 


\section{A \\ BEUCITIZEN}

informed of such possibilities and are armed with patience since the waiting time can be quite long depending on the area sought.

The other possibility for accessing rented housing is the 'normal' private market. Yet, access is difficult for people who have just arrived in the country as the market has long been dominated by private associations, like pension funds, which like the social housing associations, operate with waiting lists. Since some Danes have been put on these lists from their birth, competition for accessing private rented housing can be tough.

While the private renting market is adapting to increased demand and a lot of new accommodation is in the process of being built (some with an imposed loft on rents), the only other possibility for quickly accessing housing for foreigners is to buy their housing. Here again the situation is complicated by the existence of two types of ownerships: full property ownership and 'cooperative' property ('andel'). While the latter is cheaper, especially because it is not subject to property tax, it is also a less transparent market, difficult to access at a reasonable price without a network. At the end of the day, for many Union citizens, the only possibility for quickly establishing a home is to buy their housing. This is quite expensive, especially in the capital city, and a possibility which is far from available to all. Also, the market for student accommodation in the capital is currently close to saturation.

\subsubsection{Accessibility to rights \& redress for EU-citizens and third country nationals}

There are no specific remedies available for Union citizens and/or third country nationals. To conclude there is no evidence that Union citizens are discriminated in accessing housing or housing subsidies. It is the special set up of the rented market, especially accessible for those who have always lived in Denmark, and a shortage of rented accommodation in the big cities which make it difficult for Union citizens and other foreigners to find decent and reasonable priced housing. This affects essentially people with low resources regardless of nationality. 


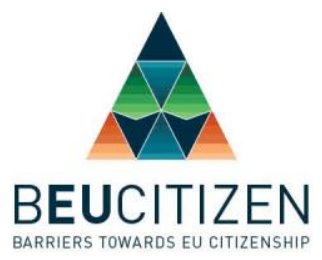

\section{Literature}

Adamo, S. (2015), WP 7 bEUcitizen, Deliverable 7.2 - Mechanims for enforcing civil rights

Andersen, J. (2013), Social forvaltningsret, 5 udg., Nyt Juridisk Forlag

Anker, J.; Christensen, I; Romose, T.S. \& T.B. Stax from the Social Research Institute ('Socialforskningsinstituttet, SFI') (2002), De almene bolige og ansvaret for de svageste (Social housing and responsibility for the weak). Can be downloaded here: http://www.sbi.dk/download/pdf/tbs_02.pdf

Bang-Pedersen, U. \& Christensen, L. H. (2015), Den civile retspleje, Pejus

Conradsen, I. M. and Gøtze, M. (2014), Administrative Appeals and ADR in Danish Administrative Law in Alternative Dispute Resolution in European Administrative Law, eds. Dragos and Neamtu, Springer

Gøtze, M. (2010), The Danish Ombudsman. A watchdog with selected preferences, Utrecht Law Review 6(1), pp. 33-50

513-177

Hartlev, M., Hybel, U. \& Morten P. B. (2013), Sundhed og jura - Sundhedsretlige perspektiver på sundhedsvaesen, sundhedspersoner og patientrettigheder, DJØF

Jacqueson, C. (2014), Union Citizenship, National report - Denmark in Neergaard, U., Jacqueson, C. and Holst-Christensen, N. (eds.), Union Citizenship: Development, Impact and Challenges. The XXVI FIDE Congress in Copenhagen, 2014, Congress Publications Vol. 2, DJØF Publishing

Jacqueson, C. (2014b), Access to social rights, report for WP 6.1, bEUcitizen

Jacqueson, C. (2106), From negligence to resistance - the case of Danish residence schemes in the light of free movement law, European Journal of Social Security (forthcoming)

Jacqueson, C. and Hartlev, M., (2014), Sygdomsbehandling i EU - en ret for de få? Om Danmark's anstrengte forhold til patienters fri bevagelighed, 6 Juristen, pp. 191-202

Ketscher, K. (2012), Retten til eksistensminimum - ret til ikke at blive diskrimineret, 4 Juristen

Ketscher, K. (2014), Socialret - Principper, rettigheder, vardier, 4. udg. DJØF

Madsen, H. B (2013), Sundhedsret (2. Udg), DJØF

Melchior, T. (2002), The Danish Judiciary, in Dahl, B. et al. (eds.) Danish Law in a 


\section{A \\ BEUCITIZEN}

European Perspective, $2^{\text {nd }}$ ed., Forlaget Thomson

Ministeriet for Sundhed og Forbyggelse (2014), Sundhedsydelser til uregistrede migranter

Nielsen, N. (2011), 'Retten til et hjem’ (The right to a Home), DJØF

Udvalg om Udlændinges ret til velfærdsydelser (Commission on foreigners' access to welfare services) (2011), Rapport om optjeningsprincippet ift. danske velfardsydelser 